(H.M. Stationery Office, 2s. 6d. each net) deal with phosgene and arsine, respectively. The methods used are colorimetric, the reagents being diphenylamine and $p$-dimethylaminobenzaldehyde in the case of phosgene, and mercuric chloride in the case of arsine. Full directions for performing the tests are given.

\section{Colonial Service Appointments}

THE following appointments and promotions in the Colonial Service have recently been made: $M$. Lunan and C. Mansfield, agricultural officers, Tanganyika Territory; A. H. Milne, veterinary officer, Nyasaland; H. W. C. Newlands, veterinary officer, Tanganyika Territory; R. H. Owen, veterinary officer, Gold Coast ; C. D. V. Georgi, senior chemist, Research Branch, chief research officer, Agricultural Department, Malaya; R. R. Glanville, senior agricultural officer, Sierre Leone, principal agricultural officer, Nigeria; W. G. Leckie, senior agricultural officer, Kenya, deputy director of agriculture, Basutoland; F. A. Squire, entomologist, Windward and Leeward Islands, entomologist, Sierra Leone; C. A. Thorold, plant pathologist, Kenya, plant pathologist, Department of Agriculture, Trinidad; R. G. M. Willan, assistant conservator of forests, Nyasaland, assistant conservator of forests, Cyprus.

\section{Prize Awards of the Paris Academy of Sciences}

THe annual public meeting of the Paris Academy of Sciences was held in December, and the customary long list of prize and medal awards for 1939 has been published. Lack of space precludes publication of the complete list of awards, most of which naturally go to French workers, but the names of the following investigators outside France who received prizes may be put on record : Prof. Nicolas Coculesco, honorary director of the Observatory and honorary professor of the Faculty of Science of the University of Bucharest, the G. de Pontécoulant Prize for his studies of celestial mechanies, especially on the development of the perturbing function; Prof. Lucien Dautrebande, of the University of Liège, a Montyon (Unhealthy Trades) Prize of 2,500 francs for his researches during the past twenty years on the toxicology of the vapours of different solvents used in industry ; Prof. Pierre Coulouma, of Lille, and director of the Institute of Anatomy of Fribourg, and Léon Devos, of the Faculty of Medicine of Lille, a Montyon Prize of 2,500 franes for their work entitled "Les zones pulmonaires. Anatomie et radiologie chez l'Homme. La lobation et la zonation des poumons. Etudes d'anatomie comparée chez l'Homme et les Mammifères".

\section{Food Rationing : Special Diets}

AT the request of the Ministry of Food, the Ministry of Health, and the Department of Health for Scotland, the Medical Research Council has appointed an expert committee "to advise from time to time on the question whether it is necessary on medical grounds to modify or supplement rations in the case of invalids and other persons on special diets". The following have accepted the Council's invitation to serve on the committee : Sir Edward Mellanby (chairman), secretary of the Medical Research Council ; Prof. L. S. P. Davidson, professor of medicine in the University of Edinburgh; the Right Hon. Lord Dawson of Penn; Prof. F. R. Fraser, professor of medicine in the British Postgraduate Medical School, London; Prof. H. P. Himsworth, professor of medicine in University College Hospital Medical School, London; Dr. R. D. Lawrence, King's College Hospital Medical School, London; Dr. R. A. McCance, reader in medicine in the University of Cambridge; Dr. J. C. Spence, Victoria Infirmary, and clinical teacher in medicine in King's College, Newcastle-on-Tyne. The committee will hold its first meeting at once, when the question of diabetic diets will be particularly considered.

\section{Announcements}

Dr. C. H. Desch retired from the post of superintendent of the Department of Metallurgy and Metallurgical Chemistry, National Physical Laboratory, on December 31 last, having attained the normal age limit. Dr. Desch will be succeeded by Dr. C. Sykes, of the Metropolitan-Vickers Research Laboratories, who will take up his duties at Teddington on March 1.

THE annual general meeting of the London and Home Counties Branch of the Institute of Physics will be held on January 25, in the lecture theatre of the Royal Institution, London, W.1. At the conclusion of the business, a lecture will be given by Dr. H. Spencer Jones, Astronomer Royal, entitled : "The Measurement of Time".

The next meeting of the Plastics Group of the Society of Chemical Industry will take the form of a joint symposium with the Faraday Society at Caxton Hall, Caxton Street, Victoria Street, S.W.1, on January 26, at 6.30 p.m. The symposium will be entitled: "Molecular Size and Structure and their Influence on the Properties of Plastics". Further information can be obtained from the Hon. Secretary of the Plastics Group, Society of Chemical Industry, Clifton House, Euston Road, London, N.W.1.

THe Hotel Dieu of Quebec, the oldest hospital in Canada, and with the possible exception of one in Mexico, the oldest hospital in North America, has recently celebrated the tercentenary of its foundation.

Tre centenary of the foundation of the Belgian Royal Academy of Medicine will be celebrated on September 19, 1941.

The New York office of the United States Public Health Services is sponsoring the formation of a Society for the Study of Syphilis for all physicians in the city who are interested in the diagnosis and treatment of the disease. 